\title{
Pengaruh Waktu dan Tegangan Listrik terhadap Kadar COD dan Fosfat pada Limbah Cair Nata De Coco Dengan Metode Hibridisasi Pipe Filter Layer-Elektrolisis (HPFLE)
}

\author{
Diky Ihsan Pratama*1, Ryan Bima Aditya ${ }^{2}$, Siti Fatimah ${ }^{3}$ \\ 1,2,3 Program Studi Teknik Kimia, Universitas Muhammadiyah Surakarta \\ Email: *1dikyihsan@yahoo.com,Bimaadityaryan@gmail.com,Sf120@ums.ac.id
}

$\begin{array}{ll}\text { Submitted } & : 22-01-2020 \\ \text { Accepted } & : 18-04-2020 \\ \text { Available online } & : 14-05-2020\end{array}$

\begin{abstract}
ABSTRAK
Penelitian ini dilakukan untuk megetahui efek dari metode HPFLE (hibridisasi pipe filter layerelektrolisis) terhadap limbah hasil pengolahan nata de coco karena limbah cair dari hasil pengolahan nata de coco belum terlalu menjadi perhatian dari pemilik industri sehingga mencemari ekosistem air. Dalam penelitian ini digunakan 2 variabel bebas yaitu variasi absorben pada pipe filter layer serta variasi tegangan dan waktu perlakuan untuk tahapan elektrolisis. Absorban yang digunakan berupa sabut kelapa, zeolit, pasir, kain, dan spon. Variasi tegangan yang digunakan adalah 5 volt, 10 volt, dan 15 volt sedangkan variasi waktunya adalah 10 menit, 30 menit, 45 menit, 60 menit, dan 75 menit. Dari variabel-variabel yang ada diketahui bahwa pada tahapan pipe filter layer memberikan efek terhadap kadar COD sebesar 13, 14\% sedangkan untuk fosfat $9,7 \%$. Untuk tegangan elektrolisis pada kadar COD yang memiliki efektifitas terbaik pada 5 volt dengan waktu perlakuan 75 menit. Sedangkan untuk fosfat tegangan yang efektif yaitu pada 5 volt dengan waktu 10 menit. Dari penelitian ini diketahui metode HPFLE memberikan pengaruh hingga kadar COD menjadi $4000 \mathrm{mg} / \mathrm{L}$ sedangkan untuk fosfat menjadi $179,01 \mathrm{mg} / \mathrm{L}$.
\end{abstract}

Kata Kunci: elektrolisis, pipe filter layer, COD, fosfat

\begin{abstract}
This research is conducting to determine effect of HPFLE (hibridisasi pipe filter layer-elektrolisis) method on the waste produced by nata de coco because the waste hs not been too much of a concern of the industrial owner, so that it pollutes the water ecosystem. In this research used two independent variables that is variations in absorbance in the pipe filter layer and variations in voltage and treatment time for the electrolysis stage. Absorbants used in the form of kelaa coir, zeolite, sand, cloth, and sponges. The voltage variations used are 5 volts, 10 volts, and 15 volts while the time variations are 10 minutes, 30 minutes, 45 minutes, 60 minutes, and 75 minutes. From the existing variables, it is known that at the pipe filter layer stage the content of COD gives an effect of $13,14 \%$ while for $9.7 \%$ of phosphate. For electrolysis voltage at the COD level which has the best effectiveness at 5 volts with 75 minutes treatment time. As for phosphate, the effective stress is at 5 volts within 10 minutes. From this research, it's known that HPFLE method gives effect to COD level to $4000 \mathrm{mg} / \mathrm{L}$ while for phosphate to $179,01 \mathrm{mg} / \mathrm{L}$
\end{abstract}

Keywords: electrolysis, pipe filter layer, COD, phosphate 


\section{TECHNO: Vol. 09 (01) Mei 2020}

\section{PENDAHULUAN}

Industri nata de coco merupakan salah satu agroindustri yang dalam proses produksinya menghasilkan limbah baik berupa limbah cair, maupun limbah padat. Limbah yang dihasilkan dari aktivitas industri nata de coco sulit dihindari, terutama untuk limbah air yang digunakan dalam proses perendaman. Pembuangan air limbah dari proses perendaman mengakibatkan pencemaran bahan organik ke perairan yang tentunya menurunkan kualitas air sedangkan bau yang tidak sedap dari limbah cair sisa fermentasi nata de coco terjadi akibat adanya kondisi anaerobik yang menghasilkan karbondioksida dan hidrogen sulfida (Fitriana $\mathrm{dkk}, 2017)$.

Menurut Azzahrani et al., (2018) karakteristik limbah nata de coco yang dihasilkan dari proses pemotongan adalah sebagai berikut:

Tabel 1. Karakteristik limbah Nata de Coco

\begin{tabular}{c|c}
\hline Parameter & Jumlah \\
\hline COD $(\mathrm{mg} / \mathrm{L})$ & 12,170 \\
\hline BOD $(\mathrm{mg} / \mathrm{L})$ & 10,440 \\
\hline TSS $(\mathrm{mg} / \mathrm{L})$ & 640 \\
\hline $\mathrm{pH}$ & 4.17 \\
\hline
\end{tabular}

Sumber: Pusat Informasi Agro-Teknologi (PIAT) UGM

Tabel 2. Persentase kandungan bahan organik dalam Nata de Coco

\begin{tabular}{ccccc}
\hline No & Parameter Uji & Hasil & Satuan & Metode \\
\hline 1 & Protein & 1,61 & $\% \mathrm{~b} / \mathrm{v}$ & Kjeldahl \\
\hline 2 & Lemak Total & 0,04 & $\%$ & Gravimetri \\
\hline 3 & Kadar Air & 97,50 & $\%$ & Gravimetri \\
\hline 4 & Kadar Abu & 0,74 & $\%$ & Gravimetri \\
\hline 5 & Karbohidrat & 0,11 & $\%$ & Gravimetri
\end{tabular}

Sumber: Analisis data primer (LPPT UGM)

Ada berbagai metode dalam pengolahan limbah cair salah satunya yaitu pengolahan limbah secara elektrokimia (elektrolisis). Pengolahan limbah secara elektrolisis dipilih karena pada proses elektrokimia tidak menggunakan bahan kimia, sehingga tidak perlu dilakukan penetralan terhadap pemakaian bahan kimia berlebih (excess chemical) (Hamid dkk., 2017). Elektrolisis merupakan proses kimia yang mengubah energi listrik menjadi energi kimia. Sel elektrolisis adalah sel elektrokimia yang menimbulkan terjadinya reaksi redoks yang tidak spontan dengan adanya energi listrik dari luar (Afandi dkk., 2017). Untuk menghasilkan hasil yang lebih baik sesuai standar maka digabungkan dengan pipe filter layer.

Teknik pipe filter layer merupakan teknik berjenjang atau berlapis dalam menggunakan adsorben sebagai penyerap limbah organik. Secara umum adsorben adalah proses pemisahan komponen tertentu dari satu fasa fluida (larutan) ke permukaan zat padat yang mengadsorbsi (adsorben). Adapun syarat-syarat untuk berjalannya suatu proses adsorbsi, yaitu adanya zat yang mengadsorbsi (adsorben), zat yang teradsorbsi (adsorbat), waktu pengocokan sampai adsorbsi berjalan seimbang (Fatimah dkk., 2016). 
Beberapa kandungan pencemar yang terdapat dalam limbah nata de coco yaitu COD dan fosfat. COD atau Chemical Oxygen Demand merupakan jumlah oksigen yang dibutuhkan untuk mengurai seluruh bahan organik yang terkandung dalam air (Nuraini dkk, 2019). Kandungan COD yang tinggi tentunya akan mengurangi kemampuan badan air dalam menjaga ekosistem. Sedangkan untuk kadar fosfat sendiri dalam buangan limbah domestik masih dalam kadar yang tinggi (Satmoko, 2010). Kandungan fosfat yang tinggi dapat menyebabkan terjadinya pertumbuhan tanaman air yang tidak terkendali (Rohman Taufiqur dkk, 2018).

\section{METODE PENELITIAN}

Metode penelitian yang digunakan adalah hibridisasi pipe filter layer-elektrolisis dimana metode ini merupakan gabungan dari dua metode yaitu pipe filter layer dan elektrolisis dengan dua variasi perlakuan. Variasi pertama yaitu waktu yang terdiri dari lima variasi $(10,30,45$, 60 dan 75 menit) dan variasi kedua yaitu tengangan yang terdiri dari tiga variasi $(5,10$, dan 15 volt).

Penelitian ini dilakukan pada bulan Oktober-Desember 2019 di Laboratorium Teknik Kimia Universitas Muhammadiyah Surakarta. Sampel limbah cair nata de coco diambil dari salah satu industri rumah tangga yang berada di daerah Kelurahan Baki, Kecamatan Grogol Kabupaten Sukoharjo.

Alat yang digunakan dalam penelitian ini meliputi; Adaptor, botol timbang, buret, Erlenmeyer $250 \mathrm{ml}$, gelas beker $500 \mathrm{ml}$, gelas ukur, hotplate, labu ukur, karet hisap, kaca arloji, magnetic stirrer, pengaduk kaca, pipet ukur, pipet volume, power supply, stopwatch, spektofotometerr UV-Vis.

Alat yang digunakan dalam penelitian ini meliputi; $\mathrm{Ag}_{2} \mathrm{SO}_{4},\left(\mathrm{NH}_{4}\right)_{2} \mathrm{MoO}_{4}, \mathrm{C}_{6} \mathrm{H}_{8} \mathrm{O}_{6}, \mathrm{HgSO}_{4}$, $\mathrm{H}_{2} \mathrm{O}, \mathrm{H}_{2} \mathrm{C}_{2} \mathrm{O}_{4}, \mathrm{H}_{2} \mathrm{SO}_{4}, \mathrm{HCl}, \mathrm{NaOH}, \mathrm{KMnO}_{4}, \mathrm{~K}_{2} \mathrm{~S}_{2} \mathrm{O}_{8}, \mathrm{~K}_{2} \mathrm{Cr}_{2} \mathrm{O}_{7}, \mathrm{C}_{20} \mathrm{H}_{14} \mathrm{O}_{4}, \mathrm{SnCl}_{2} .2 \mathrm{H}_{2} \mathrm{O}$, indikator $\mathrm{C}_{20} \mathrm{H}_{14} \mathrm{O}_{4}$.

\section{Prosedur Kerja}

\section{Pengujian Kadar Limbah Awal}

Limbah nata de coco yang telah diambil dilakukan uji kadar parameter COD dan fosfat sebagai pembanding kadar setelah perlakuan.

\section{Pipe Filter Layer}

Setelah melakukan pengujian awal, Limbah dialirkan melewati media pipe filter layer. Sususan dari media pipe filter layer adalah serabut kelapa, kain, kerikil, zeolit, dan spon. 


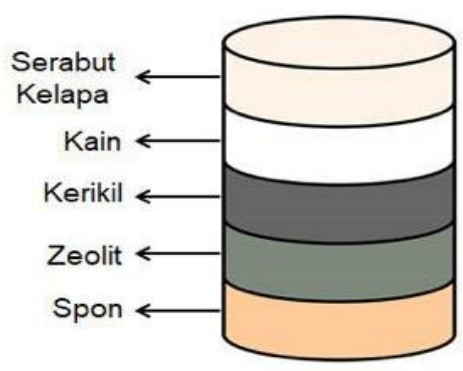

Gambar 1. Susunan pipe filter layer

\section{Elektrolisis}

Sebanyak $1000 \mathrm{~mL}$ dimasukkan kedalam gelas beker. Kemudian dipasang elektroda Aluminium sebagai anoda pada kutub (-) dan elektroda tembaga sebagai katoda dipasang pada kutub $(+)$. Kedua elektroda dimasukkan dalam gelas beker yang berisi sempel dengan jarak $5 \mathrm{~cm}$, power supply dinyalakan dengan tegangan listrik 5, 10, 15 volt. Kemudian air limbah diolah dengan waktu operasi 10, 30, 45, 60, dan 75 menit. Lalu sampel diambil dan disaring serta dilakukan proses analisa COD dan Fosfat

\section{Analisis COD}

a. Pembuatan larutan digestion solution

Campurkan 1,022 $\mathrm{g} \mathrm{K}_{2} \mathrm{Cr}_{2} \mathrm{O}_{7}$ yang telah dikeringkan pada suhu $150^{\circ} \mathrm{C}$ selama 2 jam kemudian ditambahkan $500 \mathrm{~mL}$ air suling. Kemudian tambahkan $167 \mathrm{~mL} \mathrm{H}_{2} \mathrm{SO}_{4}$ pekat dan 33,3 $\mathrm{g} \mathrm{HgSO}_{4}$. dan dinginkan pada suhu ruang dan encerkan sampai $1000 \mathrm{~mL}$.

b. Pembuatan larutan pereaksi asam sulfat

Larutkan 10,12 g kristal $\mathrm{Ag}_{2} \mathrm{SO}_{4}$ ke dalam $1000 \mathrm{~mL} \mathrm{H}_{2} \mathrm{SO}_{4}$ pekat kemudian aduk hingga larut.

c. Analisis kadar COD

Pengukuran kadar COD menggunakan metode refluks tertutup, dimana sampel ditambahkan larutan digestion solution dan larutan pereaksi asam sulfat direfluks terlebih dahulu pada suhu $150^{\circ} \mathrm{C}$ selama 2 jam. Setelah itu sampel yang sudah direfluks didinginkan perlahan-lahan sampai mencapai suhu ruang. Biarkan suspensi mengendap dan pastikan bagian yang akan diukur benar-benar jernih. Ukur serapan contoh uji atau sampel pada panjang gelombang $600 \mathrm{~nm}$.

\section{Analisis Fosfat}

a. Persiapan pengujian

Sebelum melakukan pengujian ada beberapa bahan yang mesti disiapkan terlebih dahulu antara lain; pembuatan larutan Indikator $\mathrm{C}_{20} \mathrm{H}_{14} \mathrm{O}_{4}$, pembuatan larutan $\mathrm{H}_{2} \mathrm{SO}_{4}$, pembuatan larutan $\mathrm{K}_{2} \mathrm{~S}_{2} \mathrm{O}_{8}$, pembuatan larutan $\mathrm{NaOH}$, pembuatan larutan $\left(\mathrm{NH}_{4}\right)_{2} \mathrm{MoO}_{4}$, pembuatan larutan, $\mathrm{SnCl}_{2} \cdot 2 \mathrm{H}_{2} \mathrm{O}$.

b. Analisis kadar fosfat

Penentuan kadar fosfat di lakukan dengan metode APHA-2005, metode ini menggunakan spektrofotometer UV-Vis pada panjang gelombang $690 \mathrm{~nm}$. Persiapan contoh uji, kedalam $100 \mathrm{~mL}$ contoh uji tambahkan 0,05 mL indikator PP, jika contoh uji berwarna merah jambu tambahkan larutan asam kuat tetes demi tetes sampai warna hilang. Kemudian 
tambahkan $4 \mathrm{~mL}$ ammonium molibdat dan 0,5 $\mathrm{mL}$ pereaksi $\mathrm{SnCl}_{2}$ dan diukur serapannya pada panjang gelombang $690 \mathrm{~nm}$.

\section{HASIL DAN PEMBAHASAN}

Pada penelitian ini dilakukan perlakuan pada limbah nata de coco yaitu hibridisasi pipe filter layer-elektrolisis (PFLE). Untuk mengetahui efek dari perlakuan tersebut digunakan dua parameter limbah yaitu COD dan fosfat. Berikut tabel hasil pengujian kadar awal dari limbah cair nata de coco:

Tabel 3. Hasil analisis pengaruh HPFLE

\begin{tabular}{cccc}
\hline Sampel & satuan & COD & fosfat \\
\hline original & $\mathrm{mg} / \mathrm{L}$ & 9037,5 & 50,246 \\
\hline PFLE & $\mathrm{mg} / \mathrm{L}$ & 10225 & 55,134 \\
\hline
\end{tabular}

Pada keadaan mula-mula kadar COD sebesar 9037,5 mg/L. Setelah dialirkan pada pipe filter layer kadar COD limbah menjadi $10225 \mathrm{mg} / \mathrm{L}$, sehingga efek yang diberikan dari perlakuan ini sebesar 13,14\%. Untuk perbandingan awal, kadar fosfat dari limbah cair nata de coco adalah sebesar 50,246 mg/L. Setelah dialirkan melalui pipe filter layer kadar tersebut mengalami perubahan menjadi 55,134 mg/L, artinya efek yang diberikan dari tahapan ini terhadap kadar fosfat sebesar 9,728\%. Dari analisis yang dilakukan sebagaimana terlihat pada Tabel 3, mengalami kenaikan kadar karena waktu pengambilan dan pengujian sampel tidak dalam satu hari pengujian, sehingga pertumbuhan mikroorganisme mengalami penurunan yang berakibat meningkatnya kadar COD maupun fosfat (Utami, 2013).

Tabel 4. Hasil analisis pengaruh variasi tegangan dengan waktu 10 menit

\begin{tabular}{|c|c|c|c|c|}
\hline \multirow{2}{*}{ Parameter } & \multirow{2}{*}{ Satuan } & \multicolumn{3}{|c|}{ Tegangan (volt) } \\
\hline & & 5 & 10 & 15 \\
\hline COD & $\mathrm{mg} / \mathrm{L}$ & 5740 & 6037,5 & 8725 \\
\hline Fosfat & $\mathrm{mg} / \mathrm{L}$ & 54,538 & 55,749 & 57,737 \\
\hline
\end{tabular}

Tabel 4. merupakan hasil dari perlakuan elektrolisis dengan variasi tegangan dengan waktu pengujian 10 menit. Pada parameter COD dan fosat terjadi kenaikan dari kadar awalnya. Dari sini diketahui tegangan memberikan efek yang cukup signifikan pada COD. Diantara variasi tersebut ( 5 volt, 10 volt, 15 volt) tegangan 5 volt memberikan efek yang sigifikan hingga kadar dari COD menjadi $5740 \mathrm{mg} / \mathrm{L}$. Sedangkan untuk kadar fosfat, efek terbesar terjadi pada tegangan 15 volt hingga kadar fosfat menjadi $57,737 \mathrm{mg} / \mathrm{L}$. Namun jika dilihat dari efek keamanan, maka tegangan 5 volt merupakan tegangan yang optimal karena dari kadar awal tegangan 5 volt tidak terlampau jauh sehingga cukup aman dibanding dengan tegangan lainnya.

Tabel 5. Hasil pengaruh variasi waktu

\begin{tabular}{ccccccc}
\hline \multirow{2}{*}{ Parameter } & \multirow{2}{*}{ Satuan } & \multicolumn{5}{c}{ Waktu (menit) } \\
\cline { 3 - 7 } & & 10 & 30 & 45 & 60 & 75 \\
\hline COD & $\mathrm{mg} / \mathrm{L}$ & 5740 & 8000 & 6666,67 & 46666,67 & 4000 \\
\hline Fosfat & $\mathrm{mg} / \mathrm{L}$ & 54,538 & 104,714 & 101,188 & 115,139 & 179,01 \\
\hline
\end{tabular}

Tabel 5. merupakan hasil dari perlakuan elektrolisis dengan variasi waktu. Variasi waktu yang diberikan memberikan pengaruh terhadap kadar COD dan fosfat. Pada kadar COD, 
waktu yang memberikan efektivitas terbesar terjadi pada menit ke-75 hingga mencapai kadar $4000 \mathrm{mg} / \mathrm{L}$. Hal ini terjadi karena semakin lama waktu perlakuan, memberikan waktu untuk kontaminan dalam limbah terurai. Sedangkan untuk fosfat, waktu yang memberikan efek terbesar terjadi pada menit ke-75. Namun untuk efektivitas keamanan kadar fosfat, justru perlakuan 10 menit adalah waktu terbaik karena dibandingkan kadar awal kenaikan menit ke 10 merupakan peningkatan terendah.

Pada perlakuan variasi waktu antara menit 10 dengan menit selanjutnya (30, 45, 60, dan 75 menit) terjadi kenaikan setelah dianalisis. Hal ini terjadi karena pengambilan sampel menit 10 dan sampel untuk variasi lain (30, 45, 60, dan 75 menit) terjadi pada rentang waktu yang berbeda, sehingga konsentrasi dari limbah tidak dapat dikontrol karena proses produksi dari industri belum tentu sama setiap harinya.

Jika dibandingkan dengan hasil pengujian Juherah dan M. Ansar (2018) hasil yang diperoleh pada penelitian ini berbeda. Dalam penelitian tersebut limbah yang digunakan adalah limbah laundry dalam pengukuran kadar COD dan fosfat dengan hasil bahwa peningkatan variabel tegangan dan waktu justru menurunkan kadar fosfat dan COD. Untuk penelitian ini limbah yang digunakan adalah limbah nata de coco namun peningkatan tegangan listrik dan waktu justru meningkatkan kadar fosfat sedangkan untuk COD mengalami penurunan. Hal ini dikarenakan jenis limbah nata de coco merupakan jenis limbah organik sedangkan limbah laundry merupakan jenis limbah yang mengandung surfaktan.

\section{KESIMPULAN}

Berdasarkan penelitian pengaruh tegangan dan waktu dengan metode HPFLE (Hibridisasi Pipe Filter Layer-Elektrolisis) pada limbah cair nata de coco dapat diketahui metode HPLFE memberikan pengaruh yang cukup besar pada kadar COD. Namun metode ini tidak efektif dalam menurunkan kadar fosfat karena terjadi kenaikan pada kadar fosfat.

\section{DAFTAR PUSTAKA}

Afandi, A. M., Rijal, I., \& Aziz, T. (2017). Pengaruh Waktu dan Tegangan Listrik Terhadap Limbah Cair Rumah Tangga Dengan Metode Elektrolisis. Jurnal Teknik Kimia.

Azzahrani, I. N., Davanti, F. A., Millati, R., \& Cahyanto, M. N. (2018). Effect of Hydraulic Retention Time (HRT) And Organic Loading Rate (OLR) to the Nata De Coco Anaerobic Treatment Eficiency and its Wastewater Characteristics. Agritech, 38(2), 160. https://doi.org/10.22146/agritech.24226

Badan Standardisasi Nasional. (2005). Air dan Air Limbah - Bagian 31: Cara Uji Kadar Fosfat dengan Spektrofotometer Secara Asam Askorbat. Sni 06-6989.31, 1-10. https://doi.org/SNI 06-6989.312005

Bondra, M., Setiawan, A. P., dan Nilasari, P. F. (2018). Penelitian Serabut Kelapa Sebagai Material Lantai Ecofriendly dan Biodegradable. Jurnal Intra. 6(2), 431-436.

Fatimah, S., Mumtaz, N. A., \& Hidayati, N. (2016). Penurunan Kadar COD Dan TSS dengan Menggunakan Teknik Pipe Filter Layer pada Limbah Industri Keripik Singkong. Politeknosains, 15(2), 36-43.

Fitriana, D. A., Sukiya, Harjana, T., \& Nurcahyo, H. (2017). Toksisitas Limbah Cair Nata De Coco Terhadap Kelangsungan Hidup dan Struktur Histologik Hepatopankreas Pada Ikan Nila (Oreochromis niloticus). Jurnal Prodi Biologi, 6(5), 271-280.

Hamid, R. A., Purwono, \& Oktiawan, W. (2017). Penggunaan Metode Elektrolisis Menggunakan Elektroda Karbon dengan Variasi Tegangan Listrik dan Waktu Elektrolisis dalam Penurunan Konsentrasi TSS dan COD Pada Pengolahan Air Limbah Domestik. Teknik Lingkungan, 6(1). 
Juherah, J., dan Muhammad Ansar. (2018). Pengolahan Limbah Cair Dengan Elektrokoagulasi dalam Menurunkan Kadar Fosfat (Po4) pada Limbah Laundry. Jurnal Sulolipu: Media Komunikasi Sivitas Akademika Dan Masyarakat, 18(2).

Nuraini, E., Fauziah, T., \& Lestari, F. (2019). Penentuan Nilai BOD dan COD Limbah Cair Inlet Laboratorium Pengujian Fisis Politeknik ATK Yogyakarta. Integrated Lab Journal, 07(02), 10-15. https://doi.org/10.5281/zenodo.3490306

Rohman Taufiqur, Irwan Azidi, \& Rahmi Zakiyatir. (1997). Penurunan Kadar Amoniak dan Fosfat Limbah Cair Tahu Secara Foto Katalitik Menggunakan $\mathrm{TiO}_{2}$ dan $\mathrm{H}_{2} \mathrm{O}_{2}$. Jurnal Sains Natural Universitas Nusa Bangsa, 8(2), 87-93.

Satmoko, Y. (2010). Kondisi Kualitas Air Sungai Ciliwung di Wilayah DKI Jakarta ditinjau dari Parameter Organik, Amoniak, Fosfat, Deterjen, dan Bakteri Coli. Jurnal Air Indonesia, 6(1), 34-42. Retrieved from http:// ejurnal.bppt.go.id/index.php/JAI/article/view/2452/2063

U.S., E. P. A. (1992). APHA Method 4500-P: Standard Methods for the Examination of Water and Wastewater. $552,107-1117$.

Utami, A. R. (2013). Pengolahan Limbah Cair Laundry Dengan Menggunakan Biosand Filter dan Activated Carbon. Jurnal Teknik Sipil UNTAN, 13(1).

Yustinah., Zuliani., \& Hartini. (2015). Pengaruh Konsentrasi Aktivator NaOH Pada Proses Pembuatan Arang Aktif Terhadap Kualitas Minyak Bekas Setelah Proses Pemurnian. Jurnal Teknik Kimia, (November 2015), 1-7. Retrieved from jurnal.ftumj.ac.id/index.php/semnastek 